\section{Safety and Efficacy of Halosulfuron- methyl for Yellow Nutsedge Topkill in Cool-season Turf}

\author{
J.D. Fry ${ }^{1}$ \\ Department of Horticulture, Forestry, and Recreation Resources, Kansas \\ State University, Manhattan, KS 66506
}

\section{P.H. Dernoeden ${ }^{2}$ Department of Agronomy, University of Maryland, College Park, MD 20742 \\ W.S. Upham ${ }^{3}$ and Y.L. Qian ${ }^{4}$ \\ Department of Horticulture, Forestry, and Recreation Resources, Kansas State University, Manhattan, KS 66506

\begin{abstract}
Additional index words. Agrostis palustris, Cyperus esculentus, Lolium perenne, Poa pratensis, weed control
\end{abstract}

\begin{abstract}
Field studies were conducted in Kansas and Maryland to compare the safety and efficacy of halosulfuron-methyl (HM) and bentazon for topkill of yellow nutsedge (Cyperus esculentus L.). Kentucky bluegrass (Poa pratensis L.) and creeping bentgrass (Agrostis palustris Huds.) treated with single (in Kansas) or sequential (in Maryland) HM (35 to 140 g.ha ${ }^{-1}$ ) or bentazon ( 1120 or $1680 \mathrm{~g} \cdot \mathrm{ha}^{-1}$ ) applications exhibited little injury, and treated turf had acceptable quality in all studies. Bentazon caused an unacceptable reduction in perennial ryegrass (Lolium perenne $\mathrm{L}$.) quality at $\geq 5$ weeks after treatment in four of five tests. Perennial ryegrass quality declined linearly with increasing HM rates (between 35

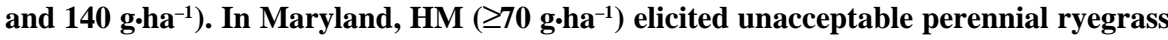
quality for 2 or 3 weeks; however, in Kansas, quality was unacceptable for $\approx 1$ week. In Kansas, yellow nutsedge topkill by HM $\left(70 \mathrm{~kg}^{-h^{-1}}\right)$ ranged from $52 \%$ to $97 \%$. A single HM application $\left(35,70\right.$, or $\left.140 \mathrm{~kg} \cdot \mathrm{ha}^{-1}\right)$ provided $>97 \%$ topkill in Maryland. Yellow nutsedge topkill by bentazon $\left(1680{\left.\mathrm{~g} \cdot h \mathrm{a}^{-1}\right)}\right.$ generally was inferior to that by $\mathrm{HM}\left(70 \mathrm{~g} \cdot h a^{-1}\right)$. Chemical names used: 3-(1-methylethyl)-1H-2,1,3-benzothiadiazin-4(3H)-one 2,2-dioxide (bentazon), methyl3-chloro-5-(4,6-dimethoxypyrimidin-2-ylcarbamoylsulfamoyl)-1-methylpyrazole4-carboxylate (halosulfuron-methyl).
\end{abstract}

Yellow nutsedge is a perennial weed that develops an extensive underground network of rhizomes and tubers. Its growth is favored by high fertility and moist soil (Stoller and Sweet, 1987), characteristics common to wellmaintained turf areas. Attempts to selectively eradicate yellow nutsedge in cool-season turf are usually unsuccessful. Monosodium acid methanearsonate (MSMA) and bentazon are contact herbicides used to kill yellow nutsedge foliage, but tubers and rhizomes are unaffected (Stoller and Sweet, 1987). Sequential MSMA and bentazon applications are re-

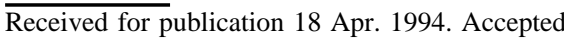
for publication 12 Oct. 1994. Kansas Agricultural Expt. Station contribution no. 94-476-J. Maryland Agricultural Expt. Station contribution no. 8794, scientific article no. A-6582. Appreciation is extended to Kevin Kamphaus for technical assistance and to Mark Willmore for providing research area. This research was supported in part by a grant from the Kansas Turfgrass Foundation. The cost of publishing this paper was defrayed in part by the payment of page charges. Under postal regulations, this paper therefore must be hereby marked advertisement solely to indicate this fact.

${ }^{1}$ Associate Professor

${ }^{2}$ Professor.

${ }^{3}$ Research Technician.

${ }^{4}$ Graduate Research Assistant.
}

Club, Topeka, Kan. HM and bentazon were applied with a $\mathrm{CO}_{2}$-pressurized sprayer calibrated to deliver 468 (Maryland) or 561 (Kansas) liters water/ha. HM was tank-mixed with a nonionic surfactant at $0.5 \%(\mathrm{v} / \mathrm{v})$; bentazon was mixed with crop oil concentrate at $1.0 \%$ (v/v). Turf quality was rated visually after application at all sites using a 1 to 10 scale (1 = brown or dead turf; $8=$ minimum acceptable quality for a golf course fairway; and $10=$ optimum color, density, and uniformity). Yellow nutsedge topkill was defined as foliage eradication. Herbicide effects on rhizomes and tubers were not evaluated. Topkill was visually evaluated in Topeka by rating plots for yellow nutsedge cover on a $0 \%$ to $100 \%$ scale. Topkill on each rating date was adjusted to account for original nutsedge populations determined in each plot before the first herbicide application using the following formula: 1 - (rating date yellow nutsedge cover $\div$ initial yellow nutsedge cover) $\times 100$. In Silver Spring, topkill was determined by counting the number of living yellow nutsedge plants per plot at 4 weeks after treatment (WAT). Data from each study were subjected to regression analysis to determine significant linear or quadratic effects of increasing HM rate on turf quality or yellow nutsedge topkill. Orthogonal contrasts between bentazon (1120 or $\left.1680 \mathrm{~g} \cdot \mathrm{ha}^{-1}\right)$ and HM (70 g.ha- ${ }^{-1}$ ) were used to compare herbicide effects on turf quality and yellow nutsedge topkill.

Silver Spring. In 1992, HM (35, 70, and $\left.140 \mathrm{~g} \cdot \mathrm{ha}^{-1}\right)$ and bentazon $\left(1200 \mathrm{~g} \cdot \mathrm{ha}^{-1}\right)$ were applied on 29 July to a 1 'Palmer' : 1 'Prelude' : 1 'Repell' perennial ryegrass. A sequential application was made to the same plots on 25 Aug. Soil was a Chillum silt loam (fine-silty, mixed, mesic Typic Hapludult) with a $\mathrm{pH}$ of 5.9 and $2.7 \%$ organic matter $(\mathrm{OM})$. Nitrogen applications were made in May, September, and October to provide $147 \mathrm{~kg} \mathrm{~N} / \mathrm{ha}$ per year. Turf was mowed once weekly at $38 \mathrm{~mm}$, and clippings were returned. Soil remained at field capacity throughout most of the study period, and no supplemental irrigation was necessary.

In a separate 1992 study of yellow nutsedge topkill, herbicides were applied to a blend of unknown Kentucky bluegrass cultivars grown on the same Chillum silt loam soil. Nitrogen was applied to provide $98 \mathrm{~kg} \mathrm{~N} / \mathrm{ha}$ per year. Turf was mowed once weekly at 50 $\mathrm{mm}$. Herbicides were applied once on 29 July 1992 at rates shown in Table 1.

In 1993, HM (35, 53, 70, and $140{\left.\mathrm{~g} \cdot \mathrm{ha}^{-1}\right)}^{-1}$ and bentazon $\left(1680 \mathrm{~g} \cdot \mathrm{ha}^{-1}\right)$ were applied on 30 June to previously nontreated plots of 'Midnight' Kentucky bluegrass, 'Southshore' creeping bentgrass, and the aforementioned perennial ryegrass blend. A second application was made to the same plots on 3 Aug. Soil characteristics and fertilization for the perennial ryegrass were the same as in 1992 . Turf was mowed twice weekly at $20 \mathrm{~mm}$, and clippings were returned. Irrigation was applied as needed to prevent stress.

'Midnight' Kentucky bluegrass also was grown on a Chillum silt loam $(6.1 \mathrm{pH} ; 3.5 \%$ $\mathrm{OM})$ and received the same fertilizer and irrigation treatments as perennial ryegrass. Turf 
was mowed once weekly at $32 \mathrm{~mm}$, and clippings were returned.

'Southshore' creeping bentgrass was seeded in Oct. 1992 on a Sassafrass sandy loam (fine loamy, siliceous, mesic Typic Hapludult) with a $5.6 \mathrm{pH}$ and $2.3 \%$ OM. A total of $220 \mathrm{~kg} \mathrm{~N} / \mathrm{ha}$ was applied to this site between Oct. 1992 and Aug. 1993. Turf was mowed twice weekly at $15 \mathrm{~mm}$, and clippings were removed. Irrigation was applied to prevent stress.

In all Maryland studies, plots measured 1.5 $\times 1.5 \mathrm{~m}$ and were arranged in randomized complete-block designs with four replications.

Manhattan (1993). HM (35, 53, and 70 $\left.\mathrm{g} \cdot \mathrm{ha}^{-1}\right)$ and bentazon (1680 g.ha $\left.{ }^{-1}\right)$ were applied to stands of 'Gator' perennial ryegrass, 'Mystic' Kentucky bluegrass, and 'Penncross' creeping bentgrass on 28 June.

Perennial ryegrass and Kentucky bluegrass were grown on a Chase silt loam (fine, montmorillonitic, mesic, Aquic, Arquidolls) with a $6.5 \mathrm{pH}$ and $>5 \%$ OM. Fertilizer was applied annually in September, November, and May to provide $147 \mathrm{~kg} \mathrm{~N} /$ ha per year. Turf was mowed two to three times weekly at $19 \mathrm{~mm}$, and clippings were returned. Irrigation was applied to prevent stress.

Creeping bentgrass was grown on a modified sand (95\% sand and 5\% clay). Turf was mowed six times weekly at $5 \mathrm{~mm}$, and clippings were removed. The site was fertilized with $245 \mathrm{~kg} \mathrm{~N} / \mathrm{ha}$ per year. When rainfall was not adequate, irrigation was applied every other day to provide $10 \mathrm{~mm}$ of water. In all Manhattan studies, plots measured $1 \times 2 \mathrm{~m}$ and were arranged in randomized complete-block designs with three replications.

Topeka (1992 and 1993). HM (35, 53, and $\left.70 \mathrm{~g} \cdot \mathrm{ha}^{-1}\right)$ and bentazon (1680 $\left.\mathrm{g} \cdot \mathrm{ha}^{-1}\right)$ were applied on 23 July 1992 and 28 June 1993 to a perennial ryegrass blend of unknown composition at Shawnee Country Club. Soil was a Ladysmith silty clay loam with a $6.3 \mathrm{pH}$ and $>5 \%$ OM. Fertilizer was applied in Septem- ber, November, and April of each year to provide $147 \mathrm{~kg} \mathrm{~N} /$ ha per year. Turf was mowed three times weekly at $13 \mathrm{~mm}$ and irrigated to prevent stress. Plots measured $1 \times 2 \mathrm{~m}$ and were arranged in a completely randomized design with three replicates.

\section{Results}

\section{Turf quality}

Silver Spring (1992 and 1993). Perennial ryegrass quality declined linearly with increasing HM rate on all rating dates, except 1 week after the first treatment and 4 and 6 weeks after the second treatment in 1992 (Table 1). Turf treated with $35 \mathrm{~g} \mathrm{HM} / \mathrm{ha}$ exhibited unacceptable quality (i.e., rating <8.0) on three of 10 rating dates. At $70 \mathrm{~g} \cdot \mathrm{ha}^{-1}$, turf quality was unacceptable on five of 10 rating dates, and at $140 \mathrm{~g} \cdot \mathrm{ha}^{-1}$ turf quality was unacceptable on eight of 10 rating dates. Acceptable quality of perennial ryegrass treated with HM at 140 g.ha ${ }^{-1}$ did not return until 6 weeks after the second application. Quality reduction of turf treated with HM was due to bleaching or chlorosis of leaf blades and sheaths, but no reduction in turf cover occurred in 1992.

Quality of perennial ryegrass treated with bentazon $\left(1120 \mathrm{~g} \cdot \mathrm{ha}^{-1}\right)$ was inferior to that of turf treated with HM $\left(70 \mathrm{~g} \cdot \mathrm{ha}^{-1}\right)$ on all rating dates in 1992 (Table 1). Turf quality was unacceptable for HM-treated $\left(70 \mathrm{~kg} \cdot \mathrm{ha}^{-1}\right)$ turf 2 and 3 weeks after the first application and 1 , 2 , and 4 weeks after the second treatment. Turf quality in bentazon-treated plots was unacceptable until the final rating date. Bentazon injury was observed initially as chlorosis, followed by necrosis of leaf blades or sheaths and a temporary reduction in turf cover. The reduction in cover was nonuniform, and injured plants recovered $\approx 6$ weeks following the second application. Nonuniformity of the damage suggested that one or more cultivars in the blend tolerated the herbicide.
In 1993, increasing HM rates resulted in a linear decline in perennial ryegrass quality on all rating dates except 2,3 , and 5 weeks after the first treatment (Table 1). HM at $35 \mathrm{~g} \cdot \mathrm{ha}^{-1}$ caused unacceptable turf quality on one of eight rating dates. Turf treated with $53 \mathrm{~g} \cdot \mathrm{ha}^{-1}$ exhibited unacceptable quality on two of eight rating dates, whereas turf treated with 70 $\mathrm{g} \cdot \mathrm{ha}^{-1}$ had unacceptable quality on three of eight rating dates. At $140 \mathrm{~g} \mathrm{HM} / \mathrm{ha}$, quality was unacceptable on four of eight rating dates.

Quality of perennial ryegrass treated with

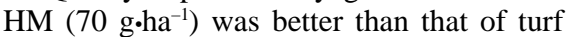
treated with bentazon (1680 g.ha-1) on six of eight rating dates in 1993 (Table 1). Bentazontreated turf did not exhibit acceptable quality on any rating date.

Creeping bentgrass quality declined linearly with increasing HM rate at 1 and 4 WAT in 1993, but quality was acceptable (>9) on all rating dates (data not shown). Creeping bentgrass treated with bentazon $\left(1680 \mathrm{~g} \cdot \mathrm{ha}^{-1}\right)$ exhibited significantly reduced quality (rating = 7.9) compared to turf treated with HM (70 $\mathrm{kg} \cdot \mathrm{ha}^{-1}$; rating $\left.=9.1\right) 2$ weeks after the first application. On all other rating dates, quality of bentazon-treated creeping bentgrass was acceptable and similar to that of HM-treated and nontreated turf. HM, regardless of rate, and bentazon had no effect on Kentucky bluegrass quality on any rating date in 1993.

Manhattan (1993). HM had no effect on quality of perennial ryegrass, creeping bentgrass, or Kentucky bluegrass (data not shown).

Quality of perennial ryegrass treated with HM (70 g.ha $\left.{ }^{-1}\right)$ was better than that of turf treated with bentazon $\left(1680 \mathrm{~g} \cdot \mathrm{ha}^{-1}\right)$ on all dates (Table 2). Bentazon-treated turf exhibited unacceptable quality between 1 and 3 WAT.

Creeping bentgrass quality was not affected by bentazon (1680 g.ha ${ }^{-1}$ ) (data not shown). Quality of Kentucky bluegrass treated with bentazon (rating $=9$ ) was reduced compared to turf treated with $\mathrm{HM}\left(70 \mathrm{~g} \cdot \mathrm{ha}^{-1}\right.$; rating

Table 1. Effect of halosulfuron-methyl (HM) and bentazon on quality of a perennial ryegrass blend after an initial and sequential application in Silver Spring, Md., in 1992 and $1993 .^{2}$

\begin{tabular}{|c|c|c|c|c|c|c|c|c|c|c|c|c|c|c|c|c|c|c|}
\hline \multirow{4}{*}{$\begin{array}{l}\text { Application } \\
\text { rate } \\
\left(\mathrm{g} \cdot \mathrm{ha}^{-1}\right)\end{array}$} & \multicolumn{18}{|c|}{ Turf quality $^{\mathrm{y}}$} \\
\hline & \multicolumn{10}{|c|}{1992} & \multicolumn{8}{|c|}{1993} \\
\hline & \multicolumn{4}{|c|}{ Weeks after first treatment } & \multicolumn{6}{|c|}{ Weeks after second treatment } & \multicolumn{5}{|c|}{ Weeks after first treatment } & \multicolumn{3}{|c|}{$\begin{array}{c}\text { Weeks after } \\
\text { second treatment }\end{array}$} \\
\hline & 1 & 2 & 3 & 4 & 1 & 2 & 3 & 4 & 5 & 6 & 1 & 2 & 3 & 4 & $\overline{5}$ & 1 & 2 & 3 \\
\hline \multicolumn{19}{|l|}{ HM } \\
\hline 0 & 9.1 & 9.4 & 8.1 & 8.9 & 8.6 & 8.8 & 8.8 & 8.1 & 8.6 & 9.7 & 9.6 & 8.3 & 8.1 & 8.3 & 8.7 & 9.3 & 9.1 & 9.5 \\
\hline 35 & 8.8 & 8.3 & 7.8 & 8.1 & 7.5 & 8.2 & 8.4 & 7.9 & 8.5 & 9.7 & 8.8 & 8.0 & 8.0 & 7.8 & 8.2 & 8.9 & 9.0 & 9.2 \\
\hline $53^{x}$ & --- & --- & --- & --- & --- & --- & --- & --- & --- & --- & 9.0 & 8.3 & 7.9 & 7.7 & 8.0 & 8.5 & 8.6 & 8.5 \\
\hline 70 & 8.8 & 7.8 & 7.5 & 8.1 & 7.4 & 7.8 & 8.5 & 7.9 & 8.1 & 9.9 & 8.4 & 8.1 & 7.8 & 7.0 & 7.6 & 8.1 & 8.5 & 8.3 \\
\hline 140 & 9.0 & 7.2 & 6.4 & 7.4 & 6.9 & 6.8 & 7.8 & 7.6 & 7.2 & 9.7 & 8.3 & 7.6 & 8.0 & 7.3 & 8.0 & 8.0 & 7.6 & 7.0 \\
\hline \multicolumn{19}{|l|}{ HM effect } \\
\hline Linear & NS & $* * *$ & $* * *$ & $* * *$ & $* * *$ & $* * *$ & $* *$ & NS & $* * *$ & NS & $* *$ & NS & NS & $*$ & NS & $* *$ & $* *$ & $* *$ \\
\hline Quadratic & NS & NS & NS & NS & $* *$ & $* *$ & NS & NS & NS & NS & NS & NS & NS & NS & NS & NS & NS & NS \\
\hline \multicolumn{19}{|l|}{ Bentazon } \\
\hline 1120 & 5.0 & 4.8 & 5.3 & 6.5 & 4.3 & 4.6 & 6.7 & 6.5 & 6.6 & 9.4 & 6.8 & 6.5 & 7.7 & 6.3 & 6.5 & 5.3 & 5.4 & 6.3 \\
\hline \multicolumn{19}{|l|}{ Contrast } \\
\hline HM $\left(70 \mathrm{~g} \cdot h \mathrm{~h}^{-1}\right)$ & & & & & & & & & & & & & & & & & & \\
\hline vs. bentazon & $* *$ & $* * *$ & $* * *$ & $* * *$ & $* * *$ & $* * *$ & $* * *$ & $* * *$ & $* * *$ & $* *$ & $* *$ & $* * *$ & NS & NS & $* *$ & $* * *$ & $* * *$ & $* * *$ \\
\hline
\end{tabular}

${ }^{\mathrm{z}}$ Herbicides initially were applied on 29 July 1992 and 30 June 1993. Sequential applications were made on 25 Aug. 1992 and 3 Aug. 1993.

y Turf quality was rated visually on a 1 to 10 scale $(1=$ brown or dead turf; $8.0=$ minimum acceptable quality for a golf course fairway; $10=$ optimum color, density, and uniformity).

${ }^{x} \mathrm{HM}$ at $53 \mathrm{~g} \cdot \mathrm{ha}^{-1}$ was evaluated in 1993 only.

Ns, *,**,*** Nonsignificant or significant at $P \leq 0.05,0.01$, or 0.001 , respectively. 
$=10)$ at 1 WAT, but treatments did not differ thereafter (data not shown).

Topeka (1992 and 1993). At 1 and 2 WAT, perennial ryegrass quality declined linearly with increasing HM rate (Table 3 ). However, only turf treated with $\mathrm{HM}$ at $70 \mathrm{~g} \cdot \mathrm{ha}^{-1}$ exhibited unacceptable quality and only at 2 WAT. Bentazon $\left(1680 \mathrm{~g} \cdot \mathrm{ha}^{-1}\right)$ caused severe injury to perennial ryegrass after application, and quality was 2.0 to 6.3 units lower than that of turf treated with $\mathrm{HM}$ at 1 to $3 \mathrm{WAT}$.

In 1993, HM rate did not affect perennial ryegrass quality (data not shown). Quality of turf treated with $\mathrm{HM}$ at $70 \mathrm{~g}^{\circ} \mathrm{ha}^{-1}$ (rating $=10$ ) was better than that of turf treated with bentazon at $1680 \mathrm{~g} \cdot \mathrm{ha}^{-1}($ rating $=8)$ at $1 \mathrm{WAT}$.

\section{Yellow nutsedge topkill}

Silver Spring. Plots treated with bentazon at $1120 \mathrm{~kg} \cdot \mathrm{ha}^{-1}$ (average of 104 plants per plot) had significantly fewer plants than nontreated plots (average of 230 plants per plot) at 4

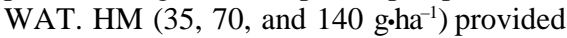
superior yellow nutsedge topkill (average of two to eight plants per plot). We did not determine whether the higher plant counts in bentazon-treated plots were due to regrowth of injured yellow nutsedge plants or subsequent shoot development from previously dormant tubers.

Topeka. Between 2 and 4 WAT in 1992, all $\mathrm{HM}$ rates provided $>95 \%$ yellow nutsedge topkill (Table 3).

Table 2. Orthogonal contrasts of halosulfuron-methyl (HM) vs. bentazon for effect on 'Gator' perennial ryegrass turf quality in Manhattan, Kan., in 1993. ${ }^{2}$

\begin{tabular}{|c|c|c|c|c|c|}
\hline \multirow{3}{*}{$\begin{array}{l}\text { Application } \\
\text { rate } \\
\left(\mathrm{g} \cdot \mathrm{ha}^{-1}\right)\end{array}$} & \multicolumn{5}{|c|}{ Turf quality ${ }^{y}$} \\
\hline & \multicolumn{5}{|c|}{ Weeks after treatment } \\
\hline & 1 & 2 & 3 & 4 & 6 \\
\hline $\mathrm{HM}$ & & & & & \\
\hline 70 & $9.3^{* * *}$ & $9.3^{* * *}$ & $9.7^{* *}$ & $10.0^{*}$ & $10.0^{\mathrm{vs}}$ \\
\hline Bentazon & & & & & \\
\hline 1680 & 6.0 & 6.0 & 7.7 & 8.0 & 9.3 \\
\hline
\end{tabular}

${ }^{2}$ Treatments were applied on 28 June.

yTurf quality was rated visually on a 1 to 10 scale ( $1=$ brown or dead turf; $8=$ minimum acceptable quality for a golf course or fairway; $10=$ optimum color, density, and uniformity).

Ns,,$* * * * * * *$ Nonsignificant or significant at $P \leq 0.05,0.01$, or 0.001 , respectively. ratings were unacceptably low on more than one rating date in three of five studies. Perennial ryegrass quality declined linearly with increasing HM rates (between 35 and 140 $\left.\mathrm{g} \cdot \mathrm{ha}^{-1}\right)$. At $140 \mathrm{~g} \mathrm{HM} / \mathrm{ha}$, HM caused unacceptable quality on more than four of eight rating dates in 1992 and 1993 in Maryland. At $140 \mathrm{~kg} \cdot \mathrm{ha}^{-1}$, and to a lesser extent at $70 \mathrm{~kg} \cdot \mathrm{ha}^{-1}$, HM elicited a yellow-orange discoloration of primarily older perennial ryegrass leaves. In Maryland, cover was reduced by $3 \%$ to $6 \%$ in perennial ryegrass treated with the high HM rates in 1993, but turf recovered within 6 weeks of the second application. Travers et al. (1993) reported that HM at $\leq 280 \mathrm{~g} \cdot \mathrm{ha}^{-1}$ was safe on perennial ryegrass. Our results, how-

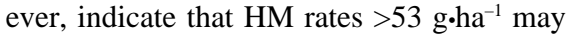
cause temporary yet unacceptable levels of injury to perennial ryegrass maintained at a height $<38 \mathrm{~mm}$.

Bentazon (1120 or $1680 \mathrm{~g} \cdot \mathrm{ha}^{-1}$ ) caused only a slight but acceptable reduction in creeping bentgrass and Kentucky bluegrass quality in two of five tests. It caused moderate injury (i.e., quality ratings 4 to 6 ) to perennial ryegrass in three of five studies, and severe injury (i.e., quality rating <4) in one of five studies. In four of five studies, bentazon caused an unacceptable injury level in perennial ryegrass, which persisted for three to five consecutive WAT.

Bentazon $\left(1680 \mathrm{~g} \cdot \mathrm{ha}^{-1}\right)$ provided $>95 \%$ topkill of yellow nutsedge within 1 WAT in Topeka in two consecutive years. However, 2 weeks were required before a significant yellow nutsedge topkill was observed with HM $\left(70 \mathrm{~g} \cdot \mathrm{ha}^{-1}\right)$. In one test, acceptable yellow nutsedge topkill was achieved between 2 and 4 WAT with HM $\left(70 \mathrm{~g} \cdot \mathrm{ha}^{-1}\right)$, whereas bentazon $\left(1680 \mathrm{~g} \cdot \mathrm{ha}^{-1}\right)$ provided acceptable suppression at only 1 WAT.

Levels of yellow nutsedge topkill were similar at $\mathrm{HM}$ rates of 35,53 , and $70 \mathrm{~g} \cdot \mathrm{ha}^{-1}$ in Kansas and Maryland. Jackson et al. (1993) stated that HM applied at $<70 \mathrm{~g} \cdot \mathrm{ha}^{-1}$ does not kill yellow nutsedge tubers. In our studies, $\mathrm{HM}$ (35 to $140 \mathrm{~g} \cdot \mathrm{ha}^{-1}$ ) was safer for application to perennial ryegrass than bentazon (1120 or

Table 3. Effect of halosulfuron-methyl (HM) and bentazon on yellow nutsedge topkill and quality of a perennial ryegrass blend in Topeka, Kan., in 1992 and $1993 .{ }^{2}$

\begin{tabular}{|c|c|c|c|c|c|c|c|c|c|c|c|c|}
\hline \multirow{4}{*}{$\begin{array}{l}\text { Application rate } \\
\left(\mathrm{g} \cdot \mathrm{ha}^{-1}\right)\end{array}$} & \multicolumn{7}{|c|}{1992} & \multicolumn{5}{|c|}{1993} \\
\hline & \multicolumn{4}{|c|}{ Yellow nutsedge topkill $(\%)^{y}$} & \multicolumn{3}{|c|}{ Turf quality $^{\mathrm{x}}$} & \multicolumn{5}{|c|}{ Yellow nutsedge topkill $(\%)$} \\
\hline & \multicolumn{4}{|c|}{ Weeks after treatment } & \multicolumn{3}{|c|}{ Weeks after treatment } & \multicolumn{5}{|c|}{ Weeks after treatment } \\
\hline & 1 & 2 & 3 & 4 & 1 & 2 & 3 & 1 & 2 & 3 & 4 & 6 \\
\hline Nontreated & 12 & 17 & 5 & 12 & 9.8 & 10.0 & 9.5 & 5 & 0 & 2 & 0 & 0 \\
\hline \multicolumn{13}{|l|}{ HM } \\
\hline 35 & 18 & 100 & 100 & 99 & 9.0 & 9.8 & 9.3 & 85 & 100 & 99 & 91 & 75 \\
\hline 53 & 19 & 100 & 100 & 99 & 9.0 & 8.5 & 8.8 & 78 & 100 & 98 & 88 & 59 \\
\hline 70 & 23 & 100 & 100 & 97 & 8.8 & 7.8 & 8.8 & 81 & 100 & 95 & 82 & 52 \\
\hline \multicolumn{13}{|l|}{ HM effect } \\
\hline Linear & NS & $* * *$ & $* * *$ & $* * *$ & $* *$ & $*$ & NS & $* * *$ & $* * *$ & $* * *$ & $* * *$ & $* *$ \\
\hline Quadratic & NS & $* * *$ & $* * *$ & $* * *$ & $*$ & NS & NS & $* * *$ & $* * *$ & $* * *$ & $* * *$ & $* * *$ \\
\hline \\
\hline 1680 & 100 & 80 & 65 & 51 & 2.5 & 5.3 & 6.8 & 93 & 99 & 93 & 76 & 51 \\
\hline \multicolumn{13}{|l|}{ Contrast } \\
\hline $\begin{array}{l}\text { HM }\left(70 \mathrm{~g} \cdot \mathrm{ha}^{-1}\right) \mathrm{vs} . \\
\text { bentazon }\end{array}$ & $* *$ & $* * *$ & $* * *$ & $* * *$ & $* * *$ & $* * *$ & $* * *$ & $* * *$ & NS & NS & NS & NS \\
\hline
\end{tabular}

${ }^{2}$ Herbicides were applied 23 July 1992 and 28 June 1993.

${ }^{y}$ Yellow nutsedge topkill was rated visually on a $0 \%$ to $100 \%$ scale.

xTurf quality was rated visually on a 1 to 10 scale $(1=$ brown or dead turf; $8=$ minimum acceptable quality for a golf course or fairway; $10=$ optimum density, color, and uniformity).

Ns, $, * *, * * * *$ Nonsignificant or significant at $P \leq 0.05,0.01$, or 0.001 , respectively. 
$1680 \mathrm{~g} \cdot \mathrm{ha}^{-1}$ ). However, $140 \mathrm{~g} \mathrm{HM} /$ ha was too phytotoxic to perennial ryegrass in Maryland. Our data also indicated that less injury occurred to perennial ryegrass at lower HM rates. Therefore, information is needed to determine the effect of relatively low HM rates $\left(35 \mathrm{~g} \cdot \mathrm{ha}^{-1}\right)$ on yellow nutsedge eradication over time.

\section{Literature Cited}

Jackson, N.E., T.E. Dutt, J.N. Travers, and J.M Goette. 1993. Control of purple and yellow nutsedge in turfgrass with MON 12000. Intl. Turfgrass Res. Soc. J. 7:269-272.

Long, C., M. Warmund, and P. Sell. 1980. Can we control yellow nutsedge in turf? Proc. North Central Weed Control Conf. 35:119.
Stoller, E.W. and R.D. Sweet. 1987. Biology and life cycle of purple and yellow nutsedge (Cyperus rotundus and Cyperus esculentus). Weed Technol. 1:66-73.

Travers, J.N., N.E. Jackson, K.D. Jolly, and D.R. Williamson. 1993. Tolerance of MON 12000 herbicide to warm and cool-season turfgrasses. Intl. Turfgrass Res. Soc. J. 7:262-268. 